\title{
A Method for the Collection and Transport of Native Grasses from the Field to the Glasshouse
}

\section{R. D. B. WHALLEY AND RAY W. BROWN}

Highlight: A simple method for transplanting native grasses from field to glasshouse with negligible mortality is suggested. The method has been used successfully in both Australia and in the United States and was far superior to other transplanting techniques. The method has also been used successfully with forbs and shrubs.

In recent years interest in the ecophysiology of native grasses, forbs, and shrubs has increased. Quite often the study of these plants under controlled laboratory or glasshouse conditions requires that they be removed from their native environment. Since these species are often quite sensitive to root disturbances and rapid changes in environmental conditions, they are difficult to transport from the field to the glasshouse without experiencing heavy mortality. The authors have found a simple, satisfactory method for transplanting a wide range of native grass and grass-like species with negligible mortality. This method can be summarized as follows:

1) The entire plant is carefully removed from the soil with a shovel or similar tool, including a relatively undisturbed ball of soil around the roots.

The authors are senior lecturer, Department of Botany, University of New England, Armidale, N.S.W. 2351 , Australia; and plant physiologist, U.S. Department of Agriculture, Forest Service, Intermountain Forest and Range Experiment Station, Forestry Sciences Laboratory, Logan, Utah.

Manuscript received December 1,1972 .
Table 1. Plants successfully collected and transported into the glasshouse.

\begin{tabular}{|c|c|c|c|c|}
\hline \multirow[b]{2}{*}{ Species } & \multirow{2}{*}{\multicolumn{2}{|c|}{ Location and elevation ( $\mathrm{ft}$ ) }} & \multicolumn{2}{|c|}{ Number of plants } \\
\hline & & & Collected & Survived \\
\hline \multicolumn{5}{|l|}{ Australia } \\
\hline \multicolumn{5}{|l|}{ Wallaby grass } \\
\hline (Danthonia sp.) & N.S.W. & 3,500 & 24 & 24 \\
\hline \multicolumn{5}{|l|}{ Kangaroo grass } \\
\hline \multirow{2}{*}{ (Themeda australis) } & S.A. & 100 & 5 & 5 \\
\hline & Qld. & 1,100 & 5 & 4 \\
\hline \multicolumn{5}{|l|}{ Nigger heads } \\
\hline (Enneapogon nigricans) & N.S.W. & 3,500 & 3 & 3 \\
\hline \multicolumn{5}{|l|}{ Swamp foxtail } \\
\hline (Pennisetum alopecuroides) & N.S.W. & 3,500 & 3 & 3 \\
\hline \multicolumn{5}{|l|}{ Windmill grass } \\
\hline (Chloris truncata) & N.S.W. & 3,500 & 3 & 3 \\
\hline \multicolumn{5}{|l|}{ Slender rat's tail } \\
\hline (Sporobolus elongatus) & N.S.W. & 3,500 & 3 & 3 \\
\hline \multicolumn{5}{|l|}{ Mat grass } \\
\hline (Hermarthria uncinata) & N.S.W. & 3,500 & 3 & 3 \\
\hline \multicolumn{5}{|l|}{ United States } \\
\hline \multicolumn{5}{|l|}{ Spikefescue } \\
\hline (Hesperochloa kingii) & Utah & 9,800 & 12 & 12 \\
\hline \multicolumn{5}{|l|}{ Spike trisetum } \\
\hline (Trisetum spicatum) & Montana & 10,400 & 12 & 12 \\
\hline \multicolumn{5}{|l|}{ Red three-awn } \\
\hline (Aristida longiseta) & Utah & 4,500 & 8 & 8 \\
\hline \multicolumn{5}{|l|}{ Bluebunch wheatgrass } \\
\hline (Agropyron spicatum) & Idaho & 6,200 & 8 & 8 \\
\hline \multicolumn{5}{|l|}{ Idaho fescue } \\
\hline (Festuca idahoensis) & Idaho & 6,200 & 6 & 6 \\
\hline \multicolumn{5}{|l|}{ Sedge } \\
\hline (Carex spp.) & Idaho & 6,200 & 6 & 5 \\
\hline \multicolumn{5}{|l|}{ Sheep fescue } \\
\hline (Festuca ovina) & Montana & 10,400 & 6 & 6 \\
\hline \multicolumn{5}{|l|}{ Alpine bluegrass } \\
\hline (Poa alpina) & Montana & 10,400 & 6 & 6 \\
\hline \multicolumn{5}{|l|}{ Prairie junegrass } \\
\hline (Koeleria cristata) & Utah & 9,800 & 6 & 6 \\
\hline \multicolumn{5}{|l|}{ Green needlegrass } \\
\hline (Stipa viridula) & Idaho & 6,200 & 6 & 6 \\
\hline \multicolumn{5}{|l|}{ Sandberg bluegrass } \\
\hline (Poa secunda) & Utah & 8,000 & 4 & 4 \\
\hline
\end{tabular}




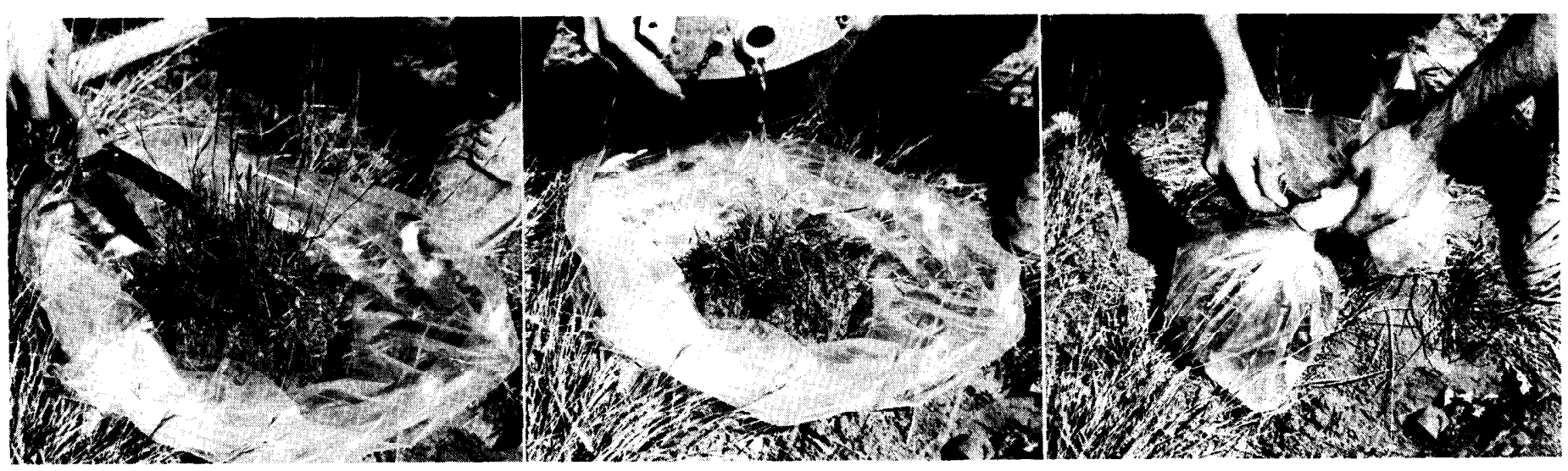

Fig. 1. (Left) The plants are placed in a plastic bag, and the leaves and culms clipped. (Center) A small quantity of water is added to dampen the soil. (Right) The plastic bag is sealed and labeled.

2) The entire plant is immediately placed in a large plastic bag, and the leaves and culms clipped to about $10 \%$ of their original height (Figure 1, left). 3) A small quantity of water is added to dampen (but not saturate) the soil (Figure 1, center), and the plastic bag is sealed and labeled (Figure 1, right). 4) The plants are shaded as much as possible from direct solar radiation during transport. In the glasshouse, the plants are placed in pots, adding a soil mix if necessary, and then watered.

A number of different species from a variety of ecological types have been successfully collected by this method in both Australia and the United States (Table 1). These plants were collected successfully at different times during the growing season, including periods of active growth. The method described was far superior to other techniques, including direct potting in the field. Plants have been stored in plastic bags for several days in a vehicle without suffering severe damage or mortality. Apparently the soil water status is not critical at the time of collection, but root disturbances are reduced if the soil is moist.

In addition to grasses and sedges, this method has been used successfully to collect many different species of forbs and shrubs (e.g. western yarrow (Achillea millefolium), dwarf clover (Trifolium nanum), alpine pussytoes (Antennaria alpina), yucca (Yucca glauca), big sagebrush (Artemisia tridentata), shadscale (Atriplex confertifolia). However, severe clipping of the aerial shoots was not necessary.

The above procedure should be strictly followed to insure success. For instance, some mortality can be expected if the plastic bags are not sealed, or if the leaves are not clipped.

\section{Development, Testing, and Evaluation of the Deep Furrow Drill Arm Assembly for the Rangeland Drill}

\author{
JERRY E. ASHER AND RICHARD E. \\ ECKERT, JR.
}

Highlight: $A$ deep-furrow drill-arm assembly for a Rangeland drill was developed, tested, and evaluated. Horizontal disk angle was the single most important factor affecting construction of an adequate furrow. This angle varied among sites and was influenced by vegetative cover and soil conditions. The final design was an assembly with an adjustable disk angle. Seedling stands in deep furrows were equal to or superior to those in standard furrows.

Many workers have shown the value of deep-furrow planting for seedling establishment and survival in varied rangeland environments (McGinnies, 1959; Eckert and Evans, 1967; Evans et al., 1967, 1970; Hull, 1970; Klomp and Hull, 1972; and Eckert et al., 1973). In these studies, furrows were constructed with hand tools or with shovel-type openers not adapted to rough, rocky rangeland conditions.

A cooperative effort was initiated in 1968 to design, test, and evaluate a drillarm assembly for the Rangeland drill to make furrows with the desired micro-

The authors are natural resource specialist, Bureau of Land Management, U.S. Department of the Interior, Albuquerque, New Mexico, and range scientist, Agricultural Research Service, U.S. Department of Agriculture, Renewable Resource Center, University of Nevada, Reno. The senior author was formerly with the BLM, Elko District, Nevada.

The work represents cooperative investiga tion of the Bureau of Land Management, U.S Department of the Interior, the Agricultural Research Service, U.S. Department of Agriculture, and the Agricultural Experiment Station, University of Nevada, Reno, Nevada (Journal Series Number 241)

Manuscript received January 15, 1973. climate characteristics and one also adapted to large-scale operations.

\section{Development and Testing}

In 1968, we modified one Rangeland drill by replacing the 20 -inch disks with 24-inch disks. Four of the ten arm assemblies were removed, and the arms were reversed so that the disks cast to the outside. This arrangement resulted in row spacing of about 20 inches. With $100 \mathrm{lb}$ weight on each arm, this equipment made good furrows in sandy and cultivated soils. In uncultivated, loamy soils, these arms could not support the additional weight of $400 \mathrm{lb}$ required to cut an adequate furrow.

In 1969; the U.S. Forest Service Equipment Development Center fabricated two "heavy-weight" drill arms with 24-inch disks and capable of supporting $400 \mathrm{lb}$ of "add-on" weight. These arms were tested on 350 acres, including a fire rehabiliation, a sagebrush spray-drill operation, and an atrazine fallow. On loam and clay-loam soils with rocks 5 to 15 inches in diameter, these arms with 400 lb of weight made furrows that averaged 3 inches deep and 4 inches wide at the top. The standard drill with standard weight ( 20 to $40 \mathrm{lb}$ ) made a furrow only 1 inch deep and 1 inch wide in moist soil and barely seratched the surface of dry soil.

Mechanical problems associated with weight additions were corrected, and six arm assemblies with 24-inch disks and various horizontal and vertical angles were tested in 1970. The horizontal angle is the pivot of the disk viewed from above. The vertical angle is the tilt of the 